\title{
Chorzy versus zdrowi. Metafory AIDS a apokalipsa zombie w World War Z
}

\section{Hubert Zięba}

Uniwersytet Jagielloński

\begin{abstract}
Susan Sontag w swoich esejach z końca lat 70. I 80. ubiegtego wieku pisata m.in. O metaforycznych znaczeniach, jakie przypisano chorobom, w tym AIDS, o ich wptywie na ludzka świadomość, o powszechnym utożsamianiu ich z karq i obcościa. W roku 2000 Kylo-Patrick R. Hart zauważyt, że w filmach fabularnych poruszajacych tematykę HIV/AIDS, wykorzystywane sa konwencje z klasycznego kina hollywoodzkiego. Choć filmowcy amerykańscy sięgaja po tę tematykę, to ukazuja ja jako moment historyczny z dwóch ostatnich dekad XX wieku. Co więcej, trudno znaleźć aktualne ujęcia jakiejkolwiek z chorób zakaźnych poza takimi, które realnie nie istnieja. W tym artykule zestawiam i uzupetniam teorie Sontag i Harta, by wykazać że popularna figura zombie ukazana w World War Z (reż. Marc Forster, 2013) powiela negatywne stereotypy wobec niektórych grup spotecznych, jakie im przypisano w związu z epidemia HIV/AIDS.
\end{abstract}

Słowa kluczowe: HIV, AIDS, choroba, metafora, zombie, science-fiction, horror, kino, film

Choć rozwój medycyny w krajach zachodnich - w tym przede wszystkim opracowanie w 1996 roku terapii HAART - był dla Andrew Sullivana wystarczającym argumentem, by już dwukrotnie ogłosić koniec epidemii AIDS (Sullivan 1996, Sullivan 2007), wirus HIV nadal pozostaje problemem. Podobnie jak na jej początku, tak i obecnie syndrom jest raczej postrzegany jako choroba tropikalna, efekt ubóstwa czy mogącej z niego wynikać niedostatecznej edukacji. Dane epidemiologiczne przeczą jednak takiemu założeniu. Choć liczba nowych zakażeń w krajach zachodnich utrzymuje się na stabilnym poziomie, pewne grupy społeczne, między innymi mniejszości rasowe i seksual.ne, są według danych epidemiologicznych obarczone większym ryzykiem, pomimo że w oficjalnym dyskursie HIV/AIDS nie mówi się już o grupach ryzyka, a o ryzykownych zachowaniach. Liczba nowych zakażeń w wyżej wymienionych grupach rośnie (Centers for Disease Control and Prevention, 2015). W ostatnim czasie kino amerykańskie głównego nurtu kilkakrotnie podjęło tematykę HIV/AIDS. Najnowsze ujęcia tematu, takie jak Witaj w klubie (reż. Jean-Marc Valleé, 2013) i Odruch serca (reż. Ryan Murphy, 2014), ale także wcześniejsze, ukazują go jako moment historyczny, umiejscowiony w latach 80. I 90. ubiegłego stulecia. Z zasady więc nie mogą być aktualnymi reprezentacjami zagadnienia, uwzględniającymi postęp medycyny i zmiany społeczne, jakie dokonały się w związku z AIDS na przestrzeni ostatnich lat. Inne, istniejące choroby zakaźne, jeśli już są jakkolwiek reperzentowane w filmach, powielają ten sam schemat: to historyczne obrazy choroby (Pappas i in. 2003: 939). W kinie są one jednak dolegliwościami fantazmatycznymi, których przykłady można znaleźć w Ludzkich dzieciach (reż. Alfonso Cuarón, 2006), Epidemii strachu (reż. Steven Soderbergh, 2011) czy World War Z (reż. Marc Forster, 2013). Pomimo tego, że żadna z chorób ukazanych w wymienionych filmach realnie nie istnieje, sposoby ich rozprzestrzeniania są znane medycynie. Konkretnym przykładem, na którym chciałbym się tu skupić, jest wspomniany World War Z. Choć film wzbudził mieszane reakcje krytyków, jest on najnowszym ujęciem motywu zombie znanego z Nocy żywych trupów (reż. George Romero, 1968). Mimo ewolucji, jaką figura zombie przeszła na prze- 
strzeni lat, zakorzeniła się w popkulturze audiowizualnej. Gry, seriale i filmy o tej tematyce jeszcze nigdy w historii kultury zachodniej nie były tak znane. Istotny jest tu jednak fakt wykorzystywania w narracjach o zombie dyskursu medycznego, gra filmowców - intencjonalna lub nie - z potencjałem znaczeniowym, jaki w dziejach ludzkości wytworzył się wokół chorób. Zombie są przedstawiani jako realne zagrożenie, nosicielami wirusa, którym mogą zakazić się ludzie poprzez bezpośredni kontakt z innymi zakażonymi. Taka gra z dyskursem medycznym, metaforami chorób, może skutkować przypisywaniu chorobom znaczeń pozamedycznych, co postaram się unaocznić na wybranym przykładzie.

Zacznę od wykazania związków między wybranymi metaforami przypisywanymi AIDS a analogicznymi motywami przedstawionymi w World War Z. Odwołam się do analizy źródeł i skutków powstania wyżej wymienionych metafor, dokonanej przez Susan Sontag. Wykorzystam też teorię KyloPatricka R. Harta, by potem zastanowić się nad funkcją obu przywołanych koncepcji w kinie amerykańskim i w kształtowaniu świadomości społecznej AIDS. Istotne będzie tu także założenie Janet McCabe, że funkcją kina jest nie tylko odzwierciedlanie rzeczywistości, lecz także jej kształtowanie (McCabe 2004: 15).

Najistotniejszą publikacją dotyczącą metafor przypisywanych AIDS (rozumianych jako zastąpienie nazwy jednego zjawiska drugim), jest esej Susan Sontag AIDS i jego metafory z 1988 roku. Choć jej wywód nie dotyczy bezpośrednio reprezentacji epidemii w kinie, to Sontag przedstawia sposoby myślenia o chorobach w takich kategoriach jak: kara, śmierć, samobójstwo czy koniec świata. Sontag postulowała konieczność zwalczania metaforycznych znaczeń chorób, gdyż bywają one źródłem opresji. Chociaż jej praca była krytykowana, główny zarzut dotyczył stosowanego przez nią homofobicznego dyskursu, nie zaś samych spostrzeżeń dotyczących głównego tematu (Miller 1989: 92). Pomimo czasu, jaki upłynął od publikacji eseju i postępu medycyny w hamowaniu rozwoju choroby, spostrzeżenia Sontag pozostają aktualne w kontekście (negatywnych) znaczeń metaforycznych, jakie przypisano AIDS, ponieważ wiele z tych metafor zdążyło głęboko zakorzenić się w świadomości społecznej, a dotychczasowe starania ich eliminacji okazały się nieskuteczne. Metaforami AIDS, do których odniosę się analizując World War Z w kontekście epidemii wirusa zmieniającego ludzi w zombie, będą: metafora śmierci/cierpienia, metafora plagi oraz metafora końca świata. Uzupełnieniem dla teorii Sontag będzie koncepcja zaczerpnięcia z filmów fantastycznonaukowych sposobów ukazywania HIV i AIDS w kinie jako czegoś obcego (other), nieludzkiego, sformułowana przez Kylo-Patricka R. Harta. Obcy mają na celu - według słów cytowanego przez Harta Stuarta Halla - wywoływanie u widzów strachu, niepokoju przed tą obcością (otherness) (Hart 2000: 16). Zdaniem Harta, zagrożenie dla ludzkości prezentowane w filmach fantastycznonaukowych mogą stanowić - oprócz istot pozaziemskich - także śmiertelne choroby zakaźne (19). Ponadto Hart dostrzegł możliwość reprezentowania AIDS w kinie za pośrednictwem metafor zakodowanych w filmie (87). Pominę jednak postulowaną przy tym intencjonalność ich wykorzystywania, gdyż nie sposób poddać ją weryfikacji. W zamian postaram się uzupełnić koncepcję Harta o konstatację, że relacja między AIDS i filmowymi obrazami chorób fantazmatycznych jest dwukierunkowa, to znaczy, że ich reprezentacje są inspirowane stereotypowymi znaczeniami, jakie wykształciły się na przestrzeni wieków w odniesieniu do znanych medycynie dolegliwości. 


\section{Metafora śmierci/cierpienia}

AIDS nadal wywołuje strach przed cierpieniem i śmiercią. Nie chodzi jednak wyłącznie o jego wymiar fizyczny, lecz także społeczny, ponieważ każda choroba "[tworzy] tożsamość odzwierciedlającą społeczne wyobrażenia na jej temat [...] a definicje społeczne bywają ważniejsze od medycznych" (Dunin 2013: 5). Strach przed wykluczeniem z powodu nosicielstwa wirusa HIV może być więc porównywalny do strachu przed cierpieniem cielesnym i śmiercią. Podobnie jest w przypadku zombie. Jak zauważył, cytowany przez Tierney Sneeda, Robert G. Weiner, one także wywołują strach, wprowadzając poczucie realności, którego brak u innych potworów (Sneed 2013). W obydwu przypadkach mamy do czynienia z trwogą przed swego rodzaju wyrokiem.

AIDS jest przede wszystkim zespołem chorób ciała, które nieleczone, prowadzą do śmierci, bardzo często w cierpieniach. Sontag sugeruje, że największy strach wywołuje cierpienie, które degraduje ciało (Sontag 1999: 124). Autorka twierdzi też, że "[największą] grozę budzą choroby postrzeganie nie tylko jako śmiertelne, lecz jako odczłowieczające - i to w sensie dosłownym" (125). Zmiana, degradacja i w końcu rozkład ludzkiego ciała wpisane są w życie człowieka, podobnie zresztą jak choroby. Te jednak, które wpływają na wygląd zewnętrzny, oddziałują zarówno na psychikę chorych, jak i zdrowych, ułatwiając jednym i drugim samodzielne postawienie diagnozy. Mogą także skutkować stereotypizacją i - w rezultacie - stygmatyzacją chorych, tak, jak miało to miejsce w przypadku AIDS. Także i za sprawą kina, w świadomości społecznej zakorzenił się obraz chorego na AIDS, którego skóra pokryta jest mięsakami Kaposiego (charakterystycznymi, ciemnymi grudkami, nowotworem rzadko spotykanym przed wybuchem epidemii). Nosicielstwo wirusa HIV nie implikuje jednak konieczności ich wystąpienia, a jeśli nawet tak się dzieje, zmiany nowotworowe niekoniecznie pojawiają się na skórze, lecz na przykład w organach wewnętrznych. Ponadto współczesne leki są w stanie powstrzymać lub nawet cofnąć rozwój mięsaków Kaposiego. Nie umniejsza to faktu, że były one wielokrotnie wykorzystywane w wizualnych reprezentacjach chorych na AIDS, na przykład w kreacji postaci Andrew Becketta (Tom Hanks) z Filadelfii (reż. Jonathan Demme, 1993), Jonathana (Dallas Roberts) z Domu na krańcu świata (reż. Michael Mayers, 2004), i ostatnio Rayon (Jared Leto) i Rona (Matthew McConaughey) w Witaj w klubie. Fakt, że zarówno wymienione, jak i inne, pominięte przykłady filmowe, są historycznymi obrazami choroby - ukazującymi czasy z początku epidemii, kiedy skuteczne terapie antyretrowirusowe nie były jeszcze opracowane - nie musi mieć wpływu na funkcjonowanie w świadomości społecznej skojarzenia owego nowotworu z nosicielstwem wirusa HIV.

Obraz ciała zombie także zakorzenił się wyobraźni widzów jako odbiegający od wyglądu zdrowego człowieka. Sposób ich wizualnej reprezentacji w World War Z nie różni się znacznie od tego zaproponowanego przez Georga Romero w Nocy żywych trupów. Choć zombie w filmie Forstera nie "wstają" z grobów, ich ciała także ulegają transformacji: skóra zmienia odcień (tak jak to ma miejsce w procesie rozkładu), pojawiają się głębokie zmarszczki i uwidaczniają się ciemne żyły, między innymi na twarzy. Nie sposób więc nie zgodzić się z Sontag, że skutkiem takiej reprezentacji chorych zarówno nosicieli wirusa HIV, jak i zombie - jest wzbudzanie strachu przed nimi. 
Zakażenie wirusem HIV jest - jak przekonuje Sontag - "przedstawiane jako dożywotnie i nieodwracalne" (Sontag 1999: 119). Autorka powołuje się na powszechne przeświadczenie o tym, że nosiciele wirusa HIV to chorzy na AIDS, którzy jeszcze nie zachorowali (119). Podobnie jest w przypadku zombie. Z punktu widzenia Tomasza Sikory, zombie zawieszeni są gdzieś pomiędzy życiem a śmiercią, między obecnością a nieobecnością (Sikora 2014: 139). Śmierć jednych i drugich jest antycypowana, ma nastąpić w relatywnie krótkim czasie. Chociaż postęp medycyny doprowadził do tego, że przewidywana długość życia nosicieli wirusa HIV nie różni się od długości życia osób nim niezakażonych, pozytywny wynik badań na obecność przeciwciał wirusa nieodmiennie traktowany jest jak wyrok śmierci dla tych, których stan materialny nie pozwala na podjęcie terapii (nie tylko w państwach afrykańskich, ale także w USA). Wynalezienie leku na AIDS z różnych względów wydaje się być kwestią drugorzędną. Dla koncernów farmaceutycznych oznaczałoby to bowiem konieczność finansowania kosztownych badań, a docelowo utratę dochodów, w razie gdyby problem HIV/ AIDS został rozwiązany. Promowanie profilaktyki - starania, by wirus się dalej nie rozprzestrzeniał, a także powstrzymanie już zakażonych od zakażania innych, także nie zdaje się leżeć w interesie tychże koncernów. Komu więc - i dlaczego - może zależeć na zachowaniu obecnego stanu rzeczy? Wydaje się, że jest to kwestia obojętności kultury dominującej na los tych, którzy z kilku powodów się w nią nie wpisują, którzy nie rokują szans na wyzdrowienie, których człowieczeństwo ta choroba zakwestionowała. Jednym z powodów ich wykluczenia - mimo upływu lat i postępów medycyny jest pogląd, że chorzy na AIDS sami są sobie winni i że swoim zachowaniem, to znaczy uprawiając seks analny lub dożylnie stosując narkotyki - popełniają "na wpół uświadomione samobójstwo" (Sontag 1999: 114). Ich zachowanie jest określane w retoryce konserwatywnej jako odbiegające od normy, nienaturalne, destruktywne w podobnym stopniu jak kanibalizm, który jest głównym popędem motywującym zombie do działania. W World War Z jest to ukazane bardzo dosłownie: zombie rozbijają szyby samochodów rękoma, a nawet głowami, tylko po to, by spróbować zaspokoić swój niepohamowany głód. Nie zważają na obrażenia, jakie sobie w ten sposób zadają. Wykazują ponadludzką odporność na rany postrzałowe, a jedynym skutecznym sposobem, by ich powstrzymać, jest mechaniczne uszkodzenie mózgu. Zakażenie wirusem HIV, analogicznie, nie oznacza zaniku popędu seksualnego, gdyż - choć jego zaburzenia są uznawane za jeden z objawów AIDS - stosunki płciowe bez zabezpieczeń pozostają jednym z głównych źródeł zakażeń. Na nosicielstwo nie wpływa także to, czy uzależnieni od narkotyków pokonają swój nałóg. Nawet pojedynczy nosiciel wirusa HIV i pojedynczy zombie, stwarzają potencjalne ryzyko zakażenia dla innych. W końcu, choć stan zdrowia nie powinien prowadzić do kwestionowania człowieczeństwa, miewało to miejsce w przeszłości, choćby właśnie w przypadku AIDS. Podobny mechanizm ujawnia się w World War Z, gdzie skutkiem zakażenia jest całkowita zmiana w klasyfikacji gatunkowej podmiotu: z człowieka na zombie. Zgodnie z przywołanymi wcześniej argumentami Sontag, metaforyczne znaczenia AIDS jako źródła cierpienia czy przyczyny śmierci i samobójstwa, znajdują swoje odzwierciedlenie w wizji apokalipsy Forstera. Transformacja człowieka w zombie jest równoznaczna z doświadczaniem gehenny i utratą podmiotowości, które w rezultacie prowadzą do śmierci. To jednak nie wszystkie powody, dla których chorzy bywają usuwani poza granice kultury dominującej. 


\section{Metafora plagi}

Według Sontag, za główną metaforę AIDS należy uznać metaforę plagi (131) - epidemii jakiejś choroby, rozumianej „nie tylko jako źródło cierpienia, lecz również jako coś, co zostało na nas zesłane" (132). Chociaż autorka krytycznie odnosi się do postrzegania w chorobie kary, zauważa, że tego typu interpretacja ma swoje korzenie wstarożytności (132). AIDS na początku epidemii określany był mianem plagi gejowskiej, ponieważ do większości zakażeń w USA w latach 80. ubiegłego wieku dochodziło właśnie wśród gejów, głównie wskutek uprawiania seksu analnego bez użycia prezerwatyw. W World War $Z$ nie ma gejów, a przynajmniej nie sposób ich wizualnie zidentyfikować. Nikt też nie uprawia seksu. Wydawać by się mogło, że plaga w tym przypadku odzwierciedla jedynie - postulowaną przez Paula Farrella - krytykę współcześnie wymykającego się spod kontroli kapitalizmu (Farrell 2013) i związanego z nim nadmiernego konsumpcjonizmu (tak wyraźną w Nocy żywych trupów), nie zaś argumenty przedstawione przez Sontag. Idąc tym tropem, należałoby wziąć pod uwagę jedną z pierwszych scen filmu. Ukazano w niej zakorkowane ulice Filadelfii (tej samej, w której Andrew Beckett grany przez Toma Hanksa umiera na AIDS), które podczas ataku zombie utrudniają wielu ludziom ucieczkę. Założenie, że $w$ ten sposób zasugerowano widzom, iż powinni wybierać inne, ekologiczne środki lokomocji, jest błędne, zważywszy na wyeksponowanie kilku symboli marek samochodów. Znaczenie metafory AIDS jako kary w World War Z to coś więcej, niż krytyka wyborów konsumenckich. To krytyka odbiegającej od dominujących norm seksualności. Zarówno zakażenie wirusem HIV, jak i transformacja ludzi w zombie, są konsekwencjami niedostosowania się do heteronormatywnych, patriarchalnych wzorców rodziny, bo AIDS jest nie tylko karą - jak ujęła to Sontag - za „zboczony seks” (Sontag 1999: 150), ale przede wszystkim - za cytowanym przez nią Jerrym Falwellem - „sądem wydanym przez Boga na społeczeństwo, które nie chce żyć według jego praw" (148). Jedyna forma współżycia płciowego dopuszczona przez Kościół katolicki to stosunek ciskobiety i cismężczyzny. Inne praktyki seksualne, w tym zarówno seks homoseksualny, jak i pozamałżeński, są zakazane pod groźbą kary niedostąpienia zbawienia (Biblia Tysiąclecia 2003). Chrześcijanin to w domyśle biały, heteroseksualny mężczyzna, głowa i opiekun rodziny. Gerry Lane (Brad Pitt), protagonista, w pełni odpowiada temu opisowi, chociaż kwestie religijne nie są poruszane w filmie, gdyż figura zombie nie współgra z biblijną wizją apokalipsy. Jedynymi bohaterami, u których można dostrzec obrączki ślubne na palcach - przyjęte przez kulturę judeochrześcijańską jako jeden z symboli małżeństwa - jest właśnie on i jego żona, i tylko ich związkowi udaje się przetrwać atak zombie. Co prawda, pod koniec filmu jeden z lekarzy z ośrodka WHO w Cardiff (Pierfrancesco Favino) też nosi obrączkę, wyznaje on jednak, że jego żona i syn padli ofiarami epidemii w Rzymie. Udowadnia to istnienie zauważonej przez Sontag i utrwalanej w świadomości społecznej binarnej opozycji wśród dotkniętych chorobą: podziału na tych, którzy przez swoje odbiegające od normy zachowanie sami sprowadzili tragedię na siebie oraz na inne, niewinne takich zachowań ofiary (150). Wyłączając ryzyko niezawinionego cierpienia, tylko przynależność do białej, amerykańskiej, heteronormatywnej rodziny opartej na patriarchacie, stwarza szansę na przetrwanie plagi zombie. Chociaż można by pozostawić w sferze domysłów odpowiedź na pytanie, dlaczego żona pracownika WHO nie jest z nim w Cardiff, lecz w Rzymie, widzowie z dużym prawdopodobieństwem mogą założyć, że grana przez niego postać nie jest Amerykaninem - zdradza go bowiem akcent. Ich rozłąka mogła być, hipotetycznie, wynikiem migracji - co, jak za chwilę udowodnię, od wieków odgrywa istotną rolę w społecznym rozumieniu sposobów rozprzestrzeniania się chorób. Kolejna hipoteza dotyczy rozstania bohaterów. Mimo narastającej 
współcześnie presji na Kościół katolicki, jego stanowisko nie dopuszcza zwolnienia z przysięgi małżeńskiej. Ci, którzy postępują wbrew niemu, popełniają grzech. Grzech, przez który nie zostaną zbawieni, jeżeli nie wyrażą żalu.

Oprócz tych, którzy nie wpisują się w definicję kultury dominującej z powodu nie heteronormatywności swojego pożądania, do grupy z niej wykluczanych w obliczu epidemii należą także imigranci, ludzie biedni oraz mniejszości etniczne i rasowe. Pochodzenie jest bowiem istotną kwestią w rozważaniach nad znaczeniem AIDS przez pryzmat powstałego w kulturze zachodniej stereotypu choroby zakaźnej, jako nieodmiennie przychodzącej z zewnątrz (134). Podobnie jak geje, którzy nie wpisują się w konserwatywną definicję rodziny jako podstawowej jednostki białego, chrześcijańskiego społeczeństwa, imigranci także pozostają odmieńcami wobec niego zewnętrznymi. Według Sontag, „istnieje związek pomiędzy koncepcją choroby a koncepcją cudzoziemskości. Ten związek kryje się [...] w samym pojęciu zła, które od niepamiętnych czasów utożsamia się ze wszystkim, co nie jest nami, co jest obce" (135). Imigracja do Stanów Zjednoczonych, zarówno legalna jak i nielegalna, najczęściej motywowana jest biedą, pragnieniem polepszenia statusu materialnego, obietnicą spełnienia się „amerykańskiego snu". Sontag stwierdza ponadto, iż "[fakt], że choroba wiązana jest z biedą i biednymi - którzy z perspektywy uprzywilejowanych [białych] wydają się »obcymi - umacnia jeszcze skojarzenie choroby z tym, co cudzoziemskie: z egzotycznym, nierzadko prymitywnym" (138). Oprócz gejów i osób dożylnie stosujących narkotyki, epidemia AIDS szybko rozprzestrzeniała się wśród biednych imigrantów i ludzi czarnych (161). Oni także są najbardziej narażeni na niebezpieczeństwo w World War $Z$, gdzie przyjęto inną perspektywę przedstawiając źródła zagrożenia niż ta z Nocy żywych trupów. Podczas gdy w filmie Romero zombie ukazani zostali jako wewnętrzne zagrożenie (interpretowane jako krytyka bezmyślnego konsumpcjonizmu - Kohn 2013) - w obrazie Forstera są niebezpieczeństwem z zewnątrz. Koncept zewnętrzności plagi zombie wobec ogółu białego społeczeństwa amerykańskiego można rozpatrywać na co najmniej dwóch płaszczyznach: geograficznej i demograficznej. W przypadku pierwszej (upatrującej źródeł choroby wprost poza granicami USA), rzekomym źródłem śmiertelnego wirusa zmieniającego ludzi w zombie, w World War $Z$ jest Azja, ponieważ to właśnie stamtąd pochodzą pierwsze informacje o jego pojawianiu się. Nie udaje się jednak tego potwierdzić. Równie dobrze wirus mógł się zrodzić gdziekolwiek, nawet na terytorium USA. Stwierdzenie braku jakichkolwiek dowodów, na poparcie tezy, że kolebką wirusa była Azja nie oznacza jednak, że uda się ją wyplenić ze świadomości społecznej, w tym ze świadomości widzów, którym sugeruje się, że choroby mogą trafiać do Stanów Zjednoczonych z zewnątrz. Wpisuje się to w klasyczny według Sontag scenariusz plagi, zgodnie z którym "uważa się, że AIDS zrodził się [w Afryce], a następnie rozprzestrzenił się na Haiti, potem na Stany Zjednoczone i Europę" (Sontag 1999: 138), mimo, że do dnia dzisiejszego nie udało się z absolutną pewnością określić jego faktycznego pochodzenia. Przykładem filmu obrazującego brak podstaw naukowych powyższej „teorii” jest Zero Patience (reż. John Greyson, 1993), musical częściowo oparty na historii zmarłego na AIDS w 1984 roku Gaetana Dugasa, geja, który przez lata był obwiniany o sprowadzenie wirusa HIV do USA. Choć stwierdzono, że oskarżenie to mija się z prawdą, przez lata miało ono wielu zwolenników i w istotny sposób wzmocniło negatywne skojarzenie AIDS z męską homoseksualnością. Szerzej na ten temat wypowiada się Tomasz Sikora (2014: 116-139). 
Na płaszczyźnie demograficznej, odnośnie przedstawianych na ekranie zombie i ich ofiar, koncept zewnętrzności źródła plagi jest jeszcze bardziej wyrazisty. Oprócz wymienionych wcześniej dwóch małżeństw, w filmie ukazano jeszcze jedno. Są nim (najprawdopodobniej nielegalni) imigranci z krajów Ameryki Łacińskiej, którzy dają schronienie rodzinie Lane'ów, kiedy ci oczekują na ewakuację. W zamian za pomoc, Gerry próbuje bezskutecznie przekonać głowę rodziny imigrantów także mężczyznę ${ }^{1}$ - by uciekali razem z nimi. Kobiety nie biorą udziału w rozmowie. Jest ona tłumaczona przez syna Latynosów, który jako jedyny członek rodziny potrafi posługiwać się językiem angielskim. Mimo że można $z$ dużym prawdopodobieństwem założyć, iż Latynosi tworzą heteroseksualną i monogamiczną parę, dominująca pozycja mężczyzny w ich przypadku nie jest równorzędna z pozycją Gerry'ego, gdyż - idąc za argumentem Sontag - imigranci nie wpisują się w strukturę amerykańskiej kultury dominującej. Są z zewnątrz i to okazuje się wystarczającym powodem, by nie mieć szans w walce o przetrwanie. Przy życiu zostaje tylko ich kilkuletni syn, który przypuszczalnie mógł urodzić się już na terytorium USA i tym samym być w świetle prawa obywatelem amerykańskim. Jego ojciec, imigrant, nie skorzystał z szansy danej mu przez białych. Zachowując odmienność zdania, sprzeciwił się subordynacji i asymilacji z kulturą dominującą, co wraz z żoną, przypłacił życiem. Nie jest to $w$ tym filmie jedyny przykład reprezentacji uznawanych za obcych wobec większości społeczeństwa. O ile można się spierać, czy ukazanie czarnego mężczyzny jako pierwszego zombie w filmie było intencjonalne, o tyle trudno polemizować z prawdziwością stwierdzenia o rasistowskim podłożu przypisywania plagom zewnętrznego pochodzenia, zważywszy na trzykrotny atak na Gerry'ego ze strony czarnoskórych zombie w ciągu kilkuminutowej sceny ucieczki z budynku. Później, gdy dociera on do rzekomej kolebki wirusa w Korei, zmienionymi w zombie są w większości ludzie rasy żółtej, włączając w to lekarza stacjonującego w tamtejszej amerykańskiej bazie wojskowej. Nawet jeśli nie jest on Amerykaninem, to nie obywatelstwo, lecz kolor skóry jest determinantą obcości. Obcym jest każdy, kto nie jest biały. Bardziej obrazowym przykładem skojarzenia tej koncepcji ze źródłem choroby jest pobyt Gerry’ego w Jerozolimie. W omawianym kontekście istotny jest fakt, że otoczone murami miasto daje tymczasowe schronienie nie tylko Żydom, ale także i Palestyńczykom. Mury okazują się, w ostatecznym rozrachunku, zbyt słabym zabezpieczeniem przed hordami zombie, którzy przedostają się do środka ponad nimi. Obwarowania stają się także przeszkodą uniemożliwiającą wielu zdrowym ucieczkę z miasta. Można spekulować, czy zombie, którzy przedostali się do Jerozolimy, byli w większości obywatelami Izraela, lecz materiał filmowy nie dostarcza wystarczających argumentów na poparcie którejkolwiek z hipotez. Duże znaczenie symboliczne ma w tym przypadku sam mur. Zwykle bowiem oddziela on to, co wewnętrzne, od tego, co zewnętrzne; chroni to, co znane, nasze, bezpieczne - przed tym, co nieznane, niebezpieczne. Obcy (zombie) dostali się do Jerozolimy zza muru, który może też symbolizować wczesną amerykańską politykę wobec AIDS. Nie tylko nie ochroniła ona obywateli USA przed chorobą (choćby przez szybszą reakcję na pierwsze jej przypadki), ale wręcz uniemożliwiła wielu chorym szukanie pomocy na zewnątrz (zakazując obrotu lekami stosowanymi w innych krajach). Rzeczony mur można bowiem pokonać tylko z jeden strony: z zewnątrz do wewnątrz. Powrót nie jest możliwy - raz zakażeni pozostają zakażonymi. Mur tworzy w powszechnej świadomości iluzoryczny podział na mniej i bardziej zagrożonych. Chociaż daje on pewnym grupom uprzywilejowanych poczucie pozornego bezpieczeństwa, skazuje na pewną śmierć obwinianych o sprowadzenie zagrożenia, i to z obydwu jego stron. W rzeczywistości, biały kolor skóry, narodo-

1 Świadczy o tym m.in. fakt, że Latynos siedzi pod ścianą w pozycji konfrontacyjnej, naprzeciwko Gerry'ego. 
wość, heteroseksualność czy monogamia nie stanowią szczepionki przeciw wirusowi HIV. Chęć realizacji własnych popędów, pochodzenie czy rasa nie powinny być łączone z chorobami, nie tylko zakaźnymi. Z punktu widzenia Sontag, bywa to bowiem źródłem inspiracji dla retoryki ksenofobicznej, którą charakteryzują „nawoływania, by zabronić wjazdu cudzoziemcom, imigrantom” (148), a której przykłady padają ostatnio z ust konserwatywnych polityków, także i polskich, w odniesieniu do fali uchodźców, uciekających do Europy z ogarniętych wojną rejonów Afryki.

\section{Metafora końca świata}

Ostatnią, choć nie najmniej ważną, metaforą przypisywaną AIDS, którą przybliżę, jest metafora końca świata. Syndrom AIDS stał się bowiem zagrożeniem transgranicznym, narażającym na niebezpieczeństwo - jak powtarza ironicznie Sontag - „przyszłość narodu, cywilizowanego społeczeństwa, całego świata" (172). Zdawać by się mogło, że to znaczenie wyklucza wcześniejsze ustalenia na temat nieheteronormatywności, pochodzenia i koloru skóry jako determinujących ryzyko zakażenia. Nie jest tak, jeśli weźmiemy pod uwagę wspomniany wcześniej podział na tych, którzy cierpienie sami na siebie sprowadzili, i cierpiących nie z własnej winy. Skoro nikt nie jest bezpieczny wobec choroby, należy uznać, że wszyscy są narażeni na niebezpieczeństwo zakażenia. Źródła znaczenia choroby jako tej, która zwiastuje koniec świata, Sontag tłumaczyła przywiązaniem społeczeństw zachodnich, w tym przede wszystkim amerykańskiego, do scenariuszy apokaliptycznych „[odzwierciedlających] potrzebę opanowania strachu przed tym, co zdaje się wymykać naszej kontroli [...] Poczucie kulturalnego kryzysu bądź porażki rodzi pragnienie, by zacząć od początku, od niezapisanej karty. Oczywiście nikt nie pożąda plagi. Ale w końcu byłaby to jakaś okazja, by zacząć wszystko na nowo" (173-174).

Atrakcyjność takiej perspektywy podyktowana jest jeszcze innymi względami. Koncepcja apokalipsy wywodzi się bezpośrednio z tradycji chrześcijańskiej, zgodnie z którą dzieje ludzkości mają nie tylko swój początek, ale także i koniec. Choć sama w sobie apokalipsa nie jest karą dla całej ludzkości, nie stanowi też obietnicy zbawienia, życia wiecznego dla wszystkich. Dostąpić go bowiem mogą jedynie ci, którzy dostosowali się i przestrzegali zasad chrześcijaństwa. Natomiast tym, którzy je złamali, wieszczone jest wieczne potępienie. W myśl nauczania Kościoła katolickiego jedynie monogamiiczny związek osób o odmiennej płci, tj. ciskobiety i cismężczyzny, zawarty przed przedstawicielem tejże instytucji, może być usankcjonowany. Wszystkie inne, nieheteroseksualne formy związków i pozamałżeńskie realizacje pożądania nie są akceptowane, są grzechem. Biorąc pod uwagę wcześniejsze rozważania nad skojarzeniem zewnętrzności źródeł plag, imigranci oraz przedstawiciele mniejszości rasowych i etnicznych, sprowadzając choroby na innych, także grzeszą, gdyż narażają ich życie na niebezpieczeństwo. Zgodnie z doktryną Kościoła katolickiego ci, którym grzechy nie zostały formalnie odpuszczone, w obliczu końca świata nie mogą liczyć na ratunek, którym dla chrześcijan jest zbawienie.

Estetyka apokalipsy zombie w World War Z nawiązuje do powszechnych apokaliptycznych wyobrażeń. Ujęcia przedstawiające płonące metropolie i uciekające w popłochu tłumy ludzi składają się na współcześnie spopularyzowaną wizję końca świata. Aby obraz ten był spójny, należy go jednak uzupełnić reprezentacjami tych, którzy przetrwają (dostąpią zbawienia) i tych, którym to nie będzie dane. Przykładem pierwszej z powyższych grup jest rodzina Lane'ów, biali Amerykanie, drugiej - nie 
tylko wymienieni wcześniej imigranci i czarni, lecz ogólnie, ludzie innych narodowości. Doskonałym potwierdzeniem jest symboliczny schemat podróży Gerry'ego w ramach zleconej mu misji. Akcja przenosi się ze Stanów Zjednoczonych kolejno na lotniskowiec, do bazy wojskowej w Korei Południowej, ogrodzonej murami Jerozolimy, i - w końcu - do laboratorium WHO w Walii. Wyłączając enklawy kontrolowane przez amerykańskich żołnierzy, reszta świata zostaje opanowana przez zombie. Apokaliptyczne znaczenie choroby w tym przypadku ukazuje potencjał Stanów Zjednoczonych w walce z kryzysem i brak owego potencjału u innych narodów. Jest też swego rodzaju szukaniem usprawiedliwienia dla ewentualnych katastrof z przyszłości oraz tych, które tak jak AIDS, już się wydarzyły. Amerykanie przedstawiani są jako ci, którzy jako jedyni są w stanie podjąć walkę o przetrwanie. Ukazanie ograniczonych zasobów, a także możliwości zapewnienia pomocy (w postaci schronienia na lotniskowcu amerykańskiej marynarki wojennej) tylko tym potrzebującym, którzy są w stanie zaoferować coś w zamian (podjęcie się misji przez Gerry'ego), jest cyniczną afirmacją systemu gospodarczego opartego na nierównościach społecznych i manifestacją amerykańskiego egocentryzmu. Jeśli wziąć pod uwagę przytoczone argumenty, ujawnia się przekaz filmu sugerujący, że tylko pełnoprawni, heteroseksualni, biali² obywatele USA, dysponujący jakimkolwiek kapitałem lub potencjałem do pracy, przetrwają epidemię śmiertelnej choroby zakaźnej. To potwierdza nierozłączność wszystkich omówionych metafor AIDS występujących w World War Z. Cierpienie i śmierć w wyniku choroby spotyka tych, którzy sami je na siebie na wpół umyślnie sprowadzili. Choroba jest więc karą, jaka ich spotyka. Rozprzestrzeniając się szybciej wśród społeczności mniejszościowych, przenikających do struktury demograficznej społeczeństwa, zagraża jednak wszystkim, co prowadzi do postrzegania AIDS jako zagrożenia globalnego. Upraszczając ten schemat można więc założyć, że rozpowszechnione w społeczeństwie metafory chorób zakaźnych, takich jak AIDS, prowadzą do kojarzenia przedstawicieli wskazanych grup społecznych z groźbą końca świata. Sontag zauważa, że dla współczesnych społeczeństw charakterystyczne jest postulowanie konieczności "podjęcia »drastycznych środków«" w obliczu takiego zagrożenia. Przygotowuje to bowiem grunt pod politykę represji (172) wobec mniejszości pozbawionych reprezentacji politycznej. To z kolei prowadzić może do katastrofy humanitarnej, czego przykłady miały miejsce w przeszłości. Holocaust jest tego przykładem. Śmierć dziesiątek milionów ludzi chorych na AIDS też.

\section{Post-AIDS-scriptum}

Omówione metafory śmierci i cierpienia, plagi i końca świata, są ze sobą ściśle związane także dlatego, że bezpośrednio wywodzą się z amerykańskiej tradycji chrześcijańskiej, a ich stosowanie może skutkować wykluczaniem ze społeczeństwa tych, z którymi się te znaczenia kojarzy. Eksplorowanie sposobów ujęcia motywu końca świata w kinie, końca spowodowanego epidemią wirusa jak ten w World War Z - skutkuje umacnianiem stereotypów związanych z chorobami zakaźnymi. Nie jest to wyraz nieskuteczności medycyny w walce z nimi, gdyż jako film - nie tylko z pogranicza horroru i fantastyki naukowej, ale w ogóle - przedstawia wydarzenia fikcyjne, niemające żadnego punktu odniesienia w materialnej rzeczywistości. Chociaż zombie z założenia mają przerażać, wykorzystywanie dyskursu medycznego w ich przedstawianiu potęguje strach przed chorobami zakaźnymi, potencjalnie zagrażającymi życiu. Wcześniej wskazałem, że poza fizycznym, mają one także

${ }^{2}$ Chociaż jednym ze współpracowników Gerry'ego jest czarnoskóry zastępca Sekretarza Generalnego ONZ Thierry Umutoni (Fana Mokoena), jest on jedynym wyjątkiem w mojej argumentacji. Jego postać nie jest zresztą bezpośrednio zagrożona atakiem zombie. 
wymiar psychiczny i społeczny. Reakcją na trwogę, zarówno chorych, jak i potencjalnie narażonych, może być milczenie, szczególnie jeśli wartościuje się drogi zakażenia, w tym omówione wcześniej praktyki seksualne. Ponadto kojarzenie chorób z konkretnymi grupami społecznymi, obcymi, wyrzuconymi poza margines dominującej większości, może skutkować wykluczeniem społecznym coraz większej liczby chorych. Prowadzi to, w rezultacie, do ich antagonizmu z kulturą dominującą. Jej białym, heteroseksualnym przedstawicielom łatwiej bowiem obserwować cierpienie obcych (biednych, czarnych, Latynosów, Azjatów, muzułmanów czy osób nieheteroseksualnych), zgodnie z przytoczonym przez Sontag przesądem, że "ludzie, którzy mają niewiele powodów, by uważać się za chronionych przed nieszczęściem, w mniejszym też stopniu odczuwają skutki nieszczęścia" (138). O wiele trudniej jest obserwować tragedię tych, zlosem których można się identyfikować. Omówione wcześniej skojarzenie chorych z obcymi zarysowuje wyraźny podział na zdrowych i chorych. Skala epidemii zombie i sposób jej ukazania w World War $Z$ tworzy kategorię elitarnej grupy tych, którzy mają predyspozycje umożliwiające im uniknięcie zakażenia. Jest ona odbiciem lustrzanym docelowych odbiorców blockbusterów. Trzon jej stanowi bowiem biała, heteroseksualna większość społeczeństwa. Chociaż w ciągu ostatnich kilku lat można było w kinie amerykańskim zaobserwować zwiększającą się asymilację przedstawicieli mniejszości, wynikającą ze zmian zachodzących w tamtejszym prawie (mam tu na myśli liberalizację polityki imigracyjnej w 2012 roku, czy też legalizację małżeństw jednopłciowych w czerwcu 2015 roku), rozszerza ona jedynie amerykańską definicję kultury dominującej o kolejne grupy. Naiwnym byłoby zakładanie, że takie włączające strategie zostaną kiedyś wykorzystane wobec reszty świata. Jak zauważa Tomasz Sikora, koncepcja ukazywania - także w kinie amerykańskim - zdrowia publicznego jako kwestii najwyższego bezpieczeństwa bywa wykorzystywana coraz częściej (Sikora 2014: 117). W omawianym kontekście życie i zdrowie wyłącznie przedstawicieli kultury dominującej w czasie globalnego kryzysu mają wystarczającą wartość, by je chronić. Podobną strategię przyjęły władze USA w pierwszych latach epidemii AIDS, kiedy to skupiono się na ochronie białej, heteroseksualnej większości społeczeństwa, ignorując los ludzi z niej wykluczonych. Według Sary Schulman, powszechny jest pogląd, że większą tragedią była śmierć kilku tysięcy osób w zamachach z 11 września 2011 roku, niż gehenna setek tysięcy gejów na przełomie lat 80. 190. ubiegłego wieku (Schulman 2012: 46). W przypadku tych drugich, do dnia dzisiejszego nikt nie został pociągnięty do odpowiedzialności za ich los, gdyż w owym czasie byli oni wykluczeni ze społeczeństwa amerykańskiego, między innymi na podstawie ich homoseksualności (47). Groźnie przy tym brzmią obietnice deportacji ze Stanów Zjednoczonych wszystkich nielegalnych imigrantów, składane przez Donalda Trumpa, ubiegającego się aktualnie o nominację partii republikańskiej w nadchodzących wyborach prezydenckich (McCarthy 2015). Filmowe reprezentacje chorób fantazmatycznych dopuszczają i w pewnym sensie oswajają z możliwością zaistnienia nadzwyczajnej sytuacji, w której decyzja o odebraniu życia choremu nie będzie stanowić żadnego dylematu moralnego. Zaskakującym nie jest to, że obrazy apokalipsy zombie biją rekordy popularności w Stanach Zjednoczonych, lecz to, że zyskały ją poza granicami USA, mimo że niosą jasny przekaz o tym, kto jest w stanie przetrwać taki kryzys. Istnieje ryzyko, że popularyzowane w ten sposób podziały społeczne zdobędą uznanie w innych krajach. W świetle wywołanej konfliktami zbrojnymi fali migracji, której w ostatnich miesiącach nieustannie stawiają czoła kolejne państwa europejskie, można zaobserwować nasilenie się retoryki ksenofobicznej wobec imigrantów szukających schronienia przed wojną. Nastroje te podsycane są przez polityków odwołujących się do omówionych wcześniej skojarzeń cudzoziemskości z chorobami. Nie sposób nie zgodzić się z Susan Sontag, że należy wystrzegać się korzystania z takich metafor, gdyż 
- jak wykazałem - mogą być krzywdzące, jeśli nie katastrofalne w skutkach. W końcu, zombie nie zawsze były utożsamiane z zagrożeniem dla zdrowia publicznego, tak jak to ma miejsce w World War Z. Przykładem koncepcji innego oddania ich istoty jest - szczegółowo omówiony przez Tomasza Sikorę - film Otto; or Up with Dead People (reż. Bruce LaBruce, 2008), historii nastoletniego zombie borykającego się z niestabilnością granicy życia i śmierci (Sikora 2014: 25). Stan zdrowia głównego bohatera w obrazie LaBruce'a nie służy wzbudzaniu strachu przed chorobą, lecz ujawnia niestabilność kategorii tożsamości. To tylko dowodzi, że ograniczoność metaforyki nie musi determinować jednego konkretnego sposobu wizualizacji - zarówno chorób, jak i zombie.

\section{Bibliografia}

Biblia Tysiąclecia. 2003. List do Efezjan. http://biblia.deon.pl; dostęp 28.10.2015.

Centers for Disease Control and Prevention. 2015. HIV in the United States: At a Glance. http://www.cdc.gov/hiv/statistics/basics/ataglance.html; dostęp: 22.10.2015.

Dean, Tim. 2008. Breeding Culture: Barebacking, Bugchasing, Giftgiving. W: „Massachusetts Review” 49, s. 80-92.

Dunin, Kinga. 2013. Zrozumieć HIV. W: Janiszewski, Jakub. Kto w Polsce ma HIV. Warszawa: Wydawnictwo Krytyki Politycznej, s. 5-9.

Farrell, Paul. 2013. 'Zombie Capitalism' a Prequel to New 'World War Z'. „MarketWatch" 26.06.2013. http://www.marketwatch.com; dostęp: 10.12.2014.

Hart, Kylo-Patrick R. 2000. The AIDS Movie. Representing a Pandemic in Film and Television. New York: Haworth Press.

Kohn, Eric. 2013. Is 'World War Z' Too Smart For Its Own Good? „Indiewire" 18.06.2013. http://www.indiewire.com; dostęp: 10.12.2014.

McCabe, Janet. 2004. Feminist Film Studies. London: Wallflower.

McCarthy, Tom. 2015. Donald Trump wants to deport 11 million migrants: is that even possible? "The Guardian" 27.08.2015. http://www.theguardian.com; dostęp: 27.10.2015.

Miller, D. A. 1989. Sontag's Urbanity. W: „October" 49, s. 91-101.

Pappas, Georgios. Seitaridis, Savvas. Akritidis, Nikolaos. Tsianos, Epaminondas. 2003. Infectious Diseases in Cinema: Virus Hunters and Killer Microbes. W: "Clinical Infectious Diseases" 37, s. 939-942.

Schulman, Sarah. 2012. The Gentrification Of The Mind. Berkeley: University of California Press.

Sikora, Tomasz. 2014. Bodies Out Of Rule. Kraków: Wydawnictwo Naukowe Uniwersytetu Pedagogicznego.

Sneed, Tierney. 2013. How »World War Z" Stands Up To The Zombie Film Genre. „US News \& World Report" 27.06.2013. http://www.usnews.com; dostęp: 10.12.2014. 
Sontag, Susan. 1999. Choroba jako metafora. Warszawa: Państwowy Instytut Wydawniczy.

Sullivan, Andrew. 1996. When Plagues End. „The New York Times” 10.11.1996.

http://www.nytimes.com; dostęp: 25.05.2015.

- - -. 2007. The Plague Ends. „The Stranger" 21.06.2007. http://www.thestranger.com; dostęp: 25.05.2015. 